\title{
PENGEMBANGAN BAHAN AJAR BERBASIS KONTEKSTUAL PADA MATERI HIMPUNAN BERBANTU VIDEO PEMBELAJARAN
}

\author{
Yulis Purwanto', Swaditya Rizki \\ ${ }^{1,2}$ FKIP Universitas Muhammadiyah Metro \\ E-mail: $\frac{\text { yulis purwanto@yahoo.co.id }}{{ }^{1)}}$
}

\begin{abstract}
The objective of this research was to know the feasibility of mathematics contextualbased learning materials on the material set using video-assisted learning. This research was a research and development $(R \& D)$. Models were used to adapt the model developed by Sugiyono, but not to stage a mass product. Subjects tested in this study was seventh grade Junior high school 1 Batanghari academic year 2014/2015. Results of the validation of teaching materials to obtain an average value of $82.14 \%$. Learning outcomes of the pilot study of small-scale was 84 and learning outcomes of large-scale was 84.33, so the contextual-based learning materials on the material set using video-assisted learning was very feasible used in learning.
\end{abstract}

Keywords: Research and Development $(R \& D)$, contextual, learning video, learning outcomes.

\section{PENDAHULUAN}

Berdasarkan observasi awal dari guru mata pelajaran matematika di kelas VII bahwa : (1) metode yang digunakan guru masih menggunakan metode konvensional. (2) tidak menggunakan bahan ajar sebagai alat bantu guru dalam menyampaikan materi sehingga keterlibatan siswa dalam proses pembelajaran sangat kurang. (3) guru sangat jarang memberikan waktu atau meminta siswa untuk menyelesaikan atau mendiskusikan suatu masalah sehingga siswa kurang termotivasi untuk belajar dan berpikir secara mandiri. (4) siswa sangat jarang diberi kesempatan untuk bekerjasama dengan teman dalam kelompok. (5) guru tersebut mengemukakan bahwa salah satu kesulitan siswa dalam mata pelajaran matematika yaitu mengenai materi himpunan, khususnya dalam menentukan irisan dan gabungan.

Observasi dan wawancara pada guru matematika kelas VII di MTs. Negeri 1 Metro, guru sudah menggunakan bahan ajar dengan pendekatan kontekstual berbantu video pembelajaran dalam penyampaian materi himpunan. 
Dengan demikian di SMP tersebut siswa tidak mengalami kesulitan dalam memahami materi himpunana. Observasi dan wawancara yang kedua dilakukan di SMP Muhammadiyah 1 Metro, guru sudah menggunakan bahan ajar dengan pendekatan kontekstual berbantu video pembelajaran dalam menyampaikan materi. Siswa sudah tidak mengalami kesulitan dalam memahami materi himpunan.

Observasi dan wawancara yang ketiga dilakukan di SMP Negeri 1 Batanghari, guru belum menggunakan bahan ajar dengan pendekatan kontekstual berbantu video pembelajaran dalam menyampaikan materi kususnya materi himpunan. Siswa banyak mengalami kesulitan dalam memahami materi-materi pelajaran matematika kususnya materi himpunan. Sehingga penelitian ini difokuskan pada SMP Negeri 1 Batanghari.

Berdasarkan permasalahan yang ditemukan di SMP Negeri 1 Batanghari perlu dikembangkan bahan ajar dengan pendekatan kontekstual berbantu video pembelajaran agar siswa lebih mudah memahami materi himpunan. Adapun tujuan penelitian ini yaitu mengetahui kelayakan bahan ajar matematika berbasis kontekstual pada materi himpunan berbantu video pembelajaran. Bahan ajar dengan pendekatan kontektual dan berbantu video pembelajaran dapat membantu siswa mengkonstruksi materi himpunan dalam kehidupan sehari-hari, sehingga hasil belajar siswa dapat meningkat.

Banyak arti dalam memaknai bahan ajar, menurut Amri dan Ahmadi (2010:159) "bahan ajar adalah segala bentuk bahan yang digunakan untuk membantu guru/instruktur dalam melaksanakan kegiatan belajar mengajar di kelas. Bahan yang dimaksud bisa berupa tertulis maupun bahan tidak tertulis". Masih Menurut Amri dan Ahmadi (2010:161) jenis-jenis bahan ajar yaitu:

a. Bahan ajar pandang (visual) terdiri dari bahan cetak (printed) seperti hand out, buku, modul, lembar kerja siswa, brosur, leaflet, wallchart, foto/gambar, dan non cetak (non printed), seperti model/maket.

b. Bahan ajar dengar (audio) seperti kaset, radio, piringan hitam, dan compact disk audio.

c. Bahan ajar pandang dengar (audio visual) seperti compact disk, film.

d. Bahan ajar multimedia interaktif (interaktive teaching maaterial) seperti CAI (Computer Assisted Instruction), compact disk (CD) multimedia pembelajaran interaktif, dan bahan ajar berbasis web (web based learning materials).

Pendekatan

kontekstual Menurut Sagala (2012:87) pendekatan kontekstual adalah:

Pendekatan kontekstual (Contextual Teaching and Learning) merupakan konsep belajar yang membantu guru mengaitkan antara 
materi yang diajarkannya dengan situasu dunia nyata siswa dan mendorong siswa membuat hubungan antara pengetahuan yang dimilikinya dengan penerapannya dalam kehidupan mereka sebagai anggota keluarga masyarakat.

Sedangkan menurut Hanafiah dan Suhana (2010:67) "Contextual Teaching Learning merupakan suatu proses pembelajaran holistik yang bertujuan untuk membelajarkan peserta didik dalam memahami bahan ajar secara bermakna (meaningfull) yang dikaitkan dengan konteks kehidupan nyata".

Video Pembelajaran atau yang disebut juga dengan media AudioVisual sedangkan Menurut Ariani dan Haryanto (2010:93) "AudioVisual adalah multimedia yang memiliki unsur-unsur yang meliputi suara, gambar, gerak dan teks". Mengenai Audio-Visual menurut Arsyad (2013:91) "Audio-Visual adalah penggambaran atau visualisasi dari narasi materi pembelajaran dan dikemas dengan singkat". Video Pembelajaran adalah media pembelajaran yang berisi suara, gambar, gerak dan teks dan dikemas dengan singkat, padat dan jelas.

Membuat dan menyusun Video Pembelajaran yang dapat digunakan dalam pembelajaran ada banyak tahapan yang harus dilakukan, menurut Ariani dan Haryanto (2010:87-88) menyatakan beberapa tahapan merancang Video Pembelajaran yaitu:

a. Menyusun struktur materi pembelajaran yang diambil dari silabus yang digunakan disekolah. Silabus yang dibangun bertitik tolak dari standar isi. Materi-materi yang disusun dan diurutkan berdasarkan kompetensi dasarnya.

b. Peracangan struktur Video Pembelajaran pembelajaran.

c. Pengumpulan data-data yang berhubungan dengan materi ajar.

d. Membangun tampilan Video Pembelajaran pembelajaran.

\section{METODE PENELITIAN}

Pada penelitian ini menggunakan jenis penelitian Research and Development (R\&D), menurut Sugiyono (2011:407) "Research and Development adalah metode penelitian yang digunakan untuk menghasilkan produk tertentu, dan menguji keefektifan produk tersebut. Penelitian R\&D merupakan penelitian yang ditunjukan untuk dapat menghasilkan suatu produk yang baru dan dapat diuji keefektifannya". Pemaparan dari pendapat tersebut dapat disimpulkan bahwa Research and Development adalah penelitian pada subjek tertentu untuk menghasilkan suatu produk baru yang dapat diuji keefektifannya.

$$
\text { Pada }
$$

menggunakan pengembangan penelitian ini model penelitian menurut Sugiyono 
(2011:409) yaitu potensi dan masalah, pengumpulan data, desain produk, validasi desain, ujicoba pemakaian, revisi produk, ujicoba produk, revisi desain, revisi produk. Pada tahap produk masal tidak dilakukan karena keterbatasan waktu dan biaya.

Teknik validasi menggunakan angket yang akan diberikan kepada tiga validator untuk mendapatkan bahan ajar yang berkualiatas dari segi bahasa maupun isi serta mendapatkan video pembelajaran yang berkualitas dari segi bahasa, suara dan gambar.

Subjek uji coba dalam penelitian ini adalah kelas VII B SMP Negeri 1 Tahun Pelajaran 2014/2015 Batanghari. Tahapan uji coba dilakukan dua kali dengan uji coba skala kecil dan skala besar. Uji coba skala kecil yang dilakukan dengan 5 siswa, 2 orang berprestasi tinggi, 1 orang berprestasi sedang, dan 2 orang berprestasi rendah. Uji coba yang kedua dilakukan dengan skala besar. Tahapan uji coba yang kedua dilakukan dengan 1 kelas siswa kelas VII B.

\section{HASIL PENELITIAN DAN PEMBAHASAN}

Penelitian pengembangan bahan ajar kontekstual berbantu video pembelajaran pada materi himpunan ini telah di uji secara teoritis, hasil belajar dari kelas kecil, dan hasil belajar dari kelas besar. Hasil penilaian validasi dan kelayakan bahan ajar kontekstual berbantu video pembelajaran pada materi himpunan dapat dilihat pada Tabel 1 berikut ini:

Tabel 1. Hasil uji ahli kelayakan bahan ajar

\begin{tabular}{|c|c|c|c|c|c|c|}
\hline \multirow{2}{*}{ No. } & \multirow{2}{*}{ Butir } & \multicolumn{3}{|c|}{ Skor } & \multirow{2}{*}{$\begin{array}{c}\Sigma \text { Skor } \\
\text { Penilaian }\end{array}$} & \multirow{2}{*}{$\begin{array}{c}\% \\
\text { Kelayakan }\end{array}$} \\
\hline & & A.I & A.II & A.III & & \\
\hline \multicolumn{7}{|c|}{ A. MATERI } \\
\hline 1 & $\begin{array}{l}\text { Isi materi memuat konsep } \\
\text { yang benar sesuai dengan } \\
\text { KI dan KD }\end{array}$ & 5 & 4 & 4 & 13 & $87,67 \%$ \\
\hline 2 & $\begin{array}{l}\text { Materi dijabarkan dengan } \\
\text { jelas }\end{array}$ & 4 & 5 & 3 & 12 & $80 \%$ \\
\hline 3 & $\begin{array}{l}\text { Materi tersusun } \\
\text { sistematis }\end{array}$ & 5 & 5 & 4 & 14 & $93,33 \%$ \\
\hline 4 & $\begin{array}{l}\text { Soal yang dibuat sesuai } \\
\text { dengan isi materi }\end{array}$ & 4 & 4 & 5 & 13 & $87,67 \%$ \\
\hline 5 & $\begin{array}{l}\text { Soal-soal latihan } \\
\text { mengacu pada tujuan } \\
\text { pembelajaran }\end{array}$ & 4 & 4 & 4 & 12 & $80 \%$ \\
\hline 6 & Soal-soal latihan & 5 & 4 & 4 & 13 & $87,67 \%$ \\
\hline
\end{tabular}




\begin{tabular}{|c|c|c|c|c|c|c|}
\hline & $\begin{array}{l}\text { mewakili indikator dari } \\
\text { KD }\end{array}$ & & & & & \\
\hline 7 & $\begin{array}{l}\text { Menggunakan rumus- } \\
\text { rumus yang valid }\end{array}$ & 4 & 5 & 4 & 13 & $87,67 \%$ \\
\hline 8 & Materi mudah dipahami & 5 & 5 & 4 & 14 & $93,33 \%$ \\
\hline \multicolumn{6}{|c|}{ Rata-rata } & $80 \%$ \\
\hline \multicolumn{7}{|c|}{ B. DESAIN BAHAN AJAR } \\
\hline 1 & $\begin{array}{l}\text { Kemenarikan } \\
\text { pengemasan desain cover }\end{array}$ & 4 & 4 & 4 & 12 & $80 \%$ \\
\hline 2 & $\begin{array}{l}\text { Ketepatan pemakaian } \\
\text { jenis huruf yang } \\
\text { digunakan dalam cover }\end{array}$ & 4 & 5 & 5 & 14 & $93,33 \%$ \\
\hline 3 & $\begin{array}{l}\text { Ketepatan layout } \\
\text { pengetikan }\end{array}$ & 4 & 4 & 5 & 13 & $87,67 \%$ \\
\hline 4 & $\begin{array}{l}\text { Konsistensi penggunaan } \\
\text { spasi, judul, dan } \\
\text { pengetikan materi }\end{array}$ & 4 & 4 & 4 & 12 & $80 \%$ \\
\hline 5 & $\begin{array}{l}\text { Kejelasan penulisan atau } \\
\text { pengetikan }\end{array}$ & 4 & 4 & 4 & 12 & $80 \%$ \\
\hline 6 & $\begin{array}{l}\text { Ketepatan penempatan } \\
\text { gambar }\end{array}$ & 4 & 4 & 5 & 13 & $87,67 \%$ \\
\hline 7 & $\begin{array}{l}\text { Kesesuaian percakapan } \\
\text { yang digunakan tokoh } \\
\text { dalam LKS }\end{array}$ & 4 & 5 & 4 & 13 & $87,67 \%$ \\
\hline 8 & $\begin{array}{l}\text { Kesesuaian } \\
\text { pengorganisasian isi LKS }\end{array}$ & 4 & 5 & 5 & 14 & $93,33 \%$ \\
\hline 9 & $\begin{array}{l}\text { Ketepatan penempatan } \\
\text { tujuan pembelajaran }\end{array}$ & 4 & 4 & 4 & 12 & $80 \%$ \\
\hline 10 & $\begin{array}{l}\text { Ketepatan penggunaan } \\
\text { balon kata }\end{array}$ & 4 & 4 & 4 & 12 & $90 \%$ \\
\hline 11 & $\begin{array}{l}\text { Kesesuaian ekspresi } \\
\text { tokoh }\end{array}$ & 4 & 5 & 5 & 14 & $93,33 \%$ \\
\hline 12 & $\begin{array}{l}\text { Kemudahan bahasa yang } \\
\text { digunakan dalam LKS }\end{array}$ & 4 & 5 & 4 & 13 & $87,67 \%$ \\
\hline \multicolumn{6}{|c|}{ Rata-rata } & $82 \%$ \\
\hline \multicolumn{7}{|c|}{ C. GURU BIDANG STUDY } \\
\hline 1 & $\begin{array}{l}\text { Isi materi bahan ajar dan } \\
\text { video pembelajaran } \\
\text { memuat konsep yang } \\
\text { benar sesuai dengan KI } \\
\text { dan KD }\end{array}$ & 4 & 4 & 4 & 12 & $80 \%$ \\
\hline 2 & $\begin{array}{l}\text { Materi bahan ajar dan } \\
\text { video pembelajaran } \\
\text { dijabarkan dengan jelas }\end{array}$ & 5 & 4 & 5 & 14 & $93,33 \%$ \\
\hline
\end{tabular}




\begin{tabular}{|c|l|c|c|c|c|c|}
\hline 3 & $\begin{array}{l}\text { Materi bahan ajar dan } \\
\text { video pembelajaran } \\
\text { tersusun sistematis }\end{array}$ & 5 & 4 & 4 & 13 & $96,67 \%$ \\
\hline 4 & $\begin{array}{l}\text { Soal yang dibuat sesuai } \\
\text { dengan isi materi }\end{array}$ & 4 & 4 & 4 & 13 & $80 \%$ \\
\hline 5 & $\begin{array}{l}\text { Soal-soal latihan } \\
\text { mengacu pada tujuan } \\
\text { pembelajaran }\end{array}$ & 4 & 5 & 5 & 14 & $93,33 \%$ \\
\hline 7 & $\begin{array}{l}\text { Soal-soal latihan } \\
\text { mewakili indikator dari } \\
\text { KD }\end{array}$ & 4 & 5 & 4 & 14 & $93,33 \%$ \\
\hline 8 & $\begin{array}{l}\text { Menggunakan rumus- } \\
\text { vumus yang valid } \\
\text { mudeo pembelajaran dipahami }\end{array}$ & 5 & 4 & 4 & 14 & $93,33 \%$ \\
\hline & Rata-rata & 5 & 15 & $87 \%$ \\
\hline
\end{tabular}

\section{AHLI MEDIA PEMBELAJARAN}

\begin{tabular}{|c|l|l|l|l|l|l|}
\hline 1 & $\begin{array}{l}\text { Penggunaan perangkat } \\
\text { lunak untuk pembuatan } \\
\text { media pembelajaran } \\
\text { Matematika dengan } \\
\text { video pembelajaran } \\
\text { bersifat efektif/tepat } \\
\text { guna. }\end{array}$ & 4 & 4 & 4 & 13 & $80 \%$ \\
\hline 2 & $\begin{array}{l}\text { Penggunaan perangkat } \\
\text { lunak untuk pembuatan } \\
\text { media pembelajaran } \\
\text { Matematika dengan } \\
\text { video pembelajaran } \\
\text { bersifat efisien/hasil } \\
\text { guna. }\end{array}$ & 4 & 5 & 5 & 14 & $93,33 \%$ \\
\hline $\begin{array}{l}\text { Rekayasa perangkat } \\
\text { lunak video pembelajaran } \\
\text { pada media pembelajaran } \\
\text { Matematika mudah } \\
\text { disimpan dalam media } \\
\text { yang lain. }\end{array}$ & 4 & 5 & 4 & 14 & $93,33 \%$ \\
\hline
\end{tabular}




\begin{tabular}{|c|c|c|c|c|c|c|}
\hline 4 & $\begin{array}{l}\text { Rekayasa perangkat } \\
\text { lunak video pembelajaran } \\
\text { pada media pembelajaran } \\
\text { Matematika mudah } \\
\text { dikelola. }\end{array}$ & 5 & 4 & 4 & 14 & $93,33 \%$ \\
\hline 5 & $\begin{array}{l}\text { Media pembelajaran } \\
\text { matematika dengan video } \\
\text { pembelajaran mudah } \\
\text { digunakan. }\end{array}$ & 4 & 4 & 4 & 12 & $80 \%$ \\
\hline 6 & $\begin{array}{l}\text { Media pembelajaran } \\
\text { Matematika dengan } \\
\text { video pembelajaran } \\
\text { sederhana } \\
\text { penggunaannya. }\end{array}$ & 4 & 5 & 5 & 14 & $93,33 \%$ \\
\hline 7 & $\begin{array}{l}\text { Media pembelajaran } \\
\text { Matematika video } \\
\text { pembelajaran } \\
\text { menggunakan software } \\
\text { yang tepat. }\end{array}$ & 4 & 4 & 5 & 13 & $87,67 \%$ \\
\hline 8 & $\begin{array}{l}\text { Media pembelajaran } \\
\text { Matematika dengan } \\
\text { video pembelajaran dapat } \\
\text { diinstalasi/dijalankan } \\
\text { dengan berbagai jenis } \\
\text { komputer yang ada. }\end{array}$ & 4 & 4 & 4 & 12 & $80 \%$ \\
\hline 9 & $\begin{array}{l}\text { Media pembelajaran } \\
\text { Matematika video } \\
\text { pembelajaran dapat } \\
\text { dijalankan dan tidak } \\
\text { mengalami masalah } \\
\text { (hang/trouble) saat } \\
\text { digunakan. }\end{array}$ & 4 & 4 & 4 & 12 & $80 \%$ \\
\hline 10 & $\begin{array}{l}\text { Icon/tool pada media } \\
\text { pembelajaran } \\
\text { Matematika dengan } \\
\text { video pembelajaran dapat } \\
\text { digunakan. }\end{array}$ & 4 & 4 & 5 & 13 & $87,67 \%$ \\
\hline 11 & $\begin{array}{l}\text { Media pembelajaran } \\
\text { Matematika dengan } \\
\text { video pembelajaran dapat } \\
\text { dimanfaatkan lagi untuk } \\
\text { pengembangan media } \\
\text { pembelajaran berbasis } \\
\text { komputer. }\end{array}$ & 4 & 5 & 4 & 13 & $87,67 \%$ \\
\hline
\end{tabular}




\begin{tabular}{|c|l|l|l|l|l|l|}
\hline 12 & $\begin{array}{l}\text { Media pembelajaran } \\
\text { Matematika dengan } \\
\text { video pembelajaran } \\
\text { dapat dimanfaatkan lagi } \\
\text { untuk pengembangan } \\
\text { media pembelajaran } \\
\text { berbasis multimedia. }\end{array}$ & 4 & 5 & 5 & 14 & $93,33 \%$ \\
\hline \multicolumn{3}{|c|}{ Rata-rata } \\
\hline \multicolumn{2}{|c|}{ Rata-rata Dari Semua Aspek } & $80 \%$ \\
\hline
\end{tabular}

Keterangan :

A.I : Ahli 1 (satu)

A.II : Ahli 2 (dua)

A.III : Ahli 3 (tiga)

Aspek materi divalidasi oleh 3 validator, didalam aspek materi ini terdapat delapan kategori. Tujuh kategori sudah masuk dalam skala penilaian sangat layak dengan persentase 81-100\% diantaranya dari butir isi materi, penjabaran materi, sususan materi yang sistematis, soal yang mengacu ke tujuan pembelajaran, soal-soal yang sudah mewakili indicator dan $\mathrm{KD}$, penggunaan rumus-rumus yang valid dan materi yang mudah dipahami. Satu kategori masuk dalam skala layak dengan persentase $61-80 \%$ yaitu pembuatan soal sesuai dengan isi materi. Diperoleh nilai rata-rata $90 \%$.

Aspek desain bahan ajar divalidasi oleh 3 validator. Desain bahan ajar terdapat 12 kategori yang dinilai terdapat tuju kategori yang masuk skala penilaian sangat layak dengan persentase 81-100\% diantaranya ketepatan pemakaian jenis huruf yang digunakan dalam cover, ketepatan layout pengetikan,

Ketepatan

penempatan gambar, kesesuaian percakapan yang digunakan tokoh dalam Bahan Ajar, kesesuaian pengorganisasian ini bahan ajar , ketepatan penggunaan balon kata dan kesesuaian gambar. Lima kategori masuk dalam kategori layak dengan persentase 61-80\% yaitu kemenarikan pengemasan desain cover, kejelasan penulisan atau pengetikan, ketepatan penempatan gambar dan ketepatan penempatan tujuan pembelajaran, Kemudahan bahasa yang digunakan dalam Bahan Ajar. Sehingga diperoleh nilai rata-rata sebesar $82 \%$

Validasi selanjutnya diperoleh dari guru bidang study matematika yang memiliki delapan aspek yang dinilai. Enam kategori masuk dalam skala penilaian sangat layak dengan persentase $81-100 \%$ diantaranya materi bahan ajar dan video pembelajaran dijabarkan dengan jelas, materi bahan ajar dan video 
pembelajaran tersusun sistematis, soal-soal latihan mengacu pada tujuan pembelajaran, soal-soal latihan mewakili indikator dari $\mathrm{KD}$, menggunakan rumus-rumus yang valid dan materi bahan ajar dan video pembelajaran mudah dipahami. Kategori yang masuk dalam persentase $61-80 \%$ atau kategori layak yaitu isi materi bahan ajar dan video pembelajaran memuat konsep yang benar sesuai dengan KI dan KD serta kategori soal yang dibuat sesuai dengan isi materi. Sehingga diperoleh nilai rata-rata sebesar $87 \%$.

Validasi dari ahli media pembelajaran terdapat 12 kategori yang dinilai. Delapan kategori masuk dalam skala penilaian sangat layak dengan persentase 81-100\% diantaranya Penggunaan perangkat lunak untuk pembuatan media pembelajaran Matematika dengan video pembelajaran bersifat efisien/hasil guna, Kategori yang masuk dalam persentase $61-80 \%$ atau kategori layak yaitu Penggunaan perangkat lunak untuk pembuatan media pembelajaran Matematika dengan video pembelajaran bersifat efektif atau tepat guna, media pembelajaran matematika dengan video pembelajaran mudah digunakan, media pembelajaran Matematika dengan video pembelajaran dapat diinstalasi atau dijalankan dengan berbagai jenis komputer yang ada dan Media pembelajaran Matematika video pembelajaran dapat dijalankan dan tidak mengalami masalah (hang or trouble) saat digunakan. Diperoleh nilai ratarata dari seluruh kategori validasi ahli media pembelajaran adalah $80 \%$.

Berdasarkan Hasil uji ahli kelayakan bahan ajar dan video pembelajaran didapatkan nilai persentase kelayakan sebesar $82,14 \%$ hal ini menunjukkan bahwa bahan ajar dan video pembelajaran sangat layak. Dengan demikian bahan ajar dan video pembelajaran dapat digunakan untuk penelian sebagai media pembelajaran.

Penelitian dilanjutkan dengan melaksanakan uji coba skala kecil dan uji coba skala besar. Hasil penelitian juga berupa nilai dari hasil belajar uji coba skala kecil dan uji coba skala besar. Uji coba skala kecil (small group) menggunakan kelas yang sama sebagai uji coba skala besar, dengan cara mengambil lima siswa dari kelas VIIB. Uji coba skala besar dilaksanakan di kelas VIIB dengan jumlah siswa 31 orang, sedangkan uji coba skala kecil dilaksanakan dengan mengambil 5 orang siswa kelas VIIB dengan rata-rata hasil belajar yaitu 84. Tahapan uji coba skala kecil bagian bahan ajar dan video pembelajaran yang perlu diperbaiki adalah dengan menambah latihan soal aplikatif agar siswa lebih paham dalam mempelajari materi. 
Berdasarkan uji coba skala besar pada siswa kelas VIIB Negeri 1 Batanghari rata-rata hasil belajar siswa tersebut mencapai 84.33 sehingga bahan ajar dan video pembelajaran dapat dinyatakan layak digunakan.

\section{KESIMPULAN DAN SARAN}

Berdasarkan hasil validasi
bahan ajar pembelajaran
matematika berbasis kontekstual
pada materi himpunan yang
dikembangkan
keseluruhan diperoleh rata-rata
semua aspek sebesar $82,14 \%$
dapat dinyatakan sangat layak. Hal
ini menunjukan bahwa bahan ajar yang dikembangkan layak digunakan sebagai bahan ajar untuk membantu peserta didikdan guru pada proses belajar mengajar.

Berdasarkan pada hasil belajar peserta didik diperoleh Uji coba skala besar dilakukan pada siswa kelas VIIB SMP Negeri 1 Batanghari. Hasil tes uji coba tersebut seluruh siswa mendapat nilai mencapai ketuntasan minimum. Rata-rata hasil belajar siswa sebesar 84.33 yang juga menunjukkan bahan ajar dan video pembelajaran matematika berbasis kontekstual pada materi Himpunan sangat layak digunakan. Bahan ajar dan video pembelajaran matematika berbasis kontekstual merupakan sumber belajar yang menarik dan memiliki banyak gambar serta dilengkapi visualisasi berupa video pembelajaran. Bahan ajar dan video pembelajaran matematika berbasis kontekstual ini hanya bersifat untuk melengkapi sumber belajar guru dan siswa akan lebih banyak dan variatif. Sehingga jangan jadikan modul matematika ini sebagai satu-satunya sumber belajar.

Supaya produk pengembangan bahan ajar dan video pembelajaran matematika berbasis kontekstual dapat dimanfaatkan secara maksimal, maka perlu diberikan beberapa saran yang terkait, di antaranya adalah : dengan cara menambahkan materi-materi, sehingga produk yang dihasilkan lebih baik. Pengembangan tidak hanya terbatas pada kontekstual namun dapat dilakukan dengan cara metode-metode atau strategi yang lain, tentunya sesuai dengan karakter tiap peserta didik yang ada di sekolah masing-masing.

\section{DAFTAR PUSTAKA}

Amri, Sofan. dan Ahmadi, Iif Khoiru. 2010. Konstruksi Pengembangan

Pembelajaran. Jakarta: Prestasi Pustaka

Ariani, Niken dan Haryanto, Dany. 2010. Pembelajaran Multi Media di Sekolah (Pedoman Pembelajaran 
Inspiratif,Konstruktif, dan Prospektif). Jakarta: Prestasi Pustaka.

Arsyad, Azhar. 2013. Media Pembelajaran. jakarta: GrafindoPersada

Hanafiah, Nanang dan Suhana, Cucu. 2010. Konsep Strategi Pembelajaran. Bandung: PT Refika Aditama.
Sagala, Syaiful. 2012. Konsep dan Makna Pembelajaran. Bandung: Alfabeta.

Sugiyono. 2011. Metode Penelitian Pendidikan (Pendekatan Kuantitatif, Kualitatif, dan $R \& D)$. Bandung: Alfabeta. 